\title{
Relation between Quality of Life and Sex of Patients Post Coronary Artery Bypass Surgery
}

\author{
Seham Mohamed Mahmoud, Clinical Instructor \\ Medical Surgical Nursing, Faculty of Nursing, Alexandria University \\ Sanaa Mohamed Ahmed Alaa Eldin, Professor \\ Medical Surgical Nursing, Faculty of Nursing, Alexandria University \\ Rasha Aly Yakout Aly Hussein, Lecturer \\ Medical Surgical Nursing, Faculty of Nursing, Alexandria University
}

\begin{abstract}
Coronary artery disease (CAD) is the most prevalent of heart diseases and the main cause of mortalities in the world today which affect patients' QOL. Quality of life has emerged as an important concept and outcome in health and health care. The concept of quality of life refers to a person or groups perceived physical and mental health over time. Women with coronary artery disease report worse QOL after coronary artery bypass surgery when compared with male. A quality of life approach works to ensure that the level of the well-being of people remains high despite the possibility of increasing number of people with disabilities or declining abilities. Objective: The study aimed to identify the relation between quality of life and sex of patients post coronary artery bypass surgery. Setting: The study was conducted at the open heart outpatient clinic (male \& female) at Alexandria Main University Hospital and Shark El Medina Hospital. Subjects: A convenience sample of 160 adult patients after CABG, their age ranged from 21 up to 60. Tool: One tool was used by the researcher to collect the data; Quality of Life of Adult Patients Post Coronary Artery Bypass Surgery. It was divided into two parts; Part I: Sociodemographic data sheet, Part II: "Euro Quality of life-5 Dimensions (EQ-5D) structure interview schedule". Results: Findings of the present study revealed that males have higher mean score and higher quality of life related to mobility, self-care and usual activities as compared with females. There is a high statistical significant relation between overall average score for EQ-5D and Euro Quality of Life Visual Analogue Scale (EQVAS) and determinant length period postoperatively. The determinant length period postoperatively of the study patients is significantly associated with difference in dimension scores of mobility, self-care, usual activities pain/discomfort, anxiety/depression dimensions. Moreover group2 (post three months post operatively) have higher mean score and higher quality of life related to these dimensions as compared to groupl (post one month and half post operatively. Conclusion: $C A B G$ surgery improves patients $Q O L$, but men achieved more improvement than women. Patients' QOL post three months was better than patients' QOL post one month and half. Recommendations: Standards of care and guidelines should be developed to improve the patient's quality of life post CABG especially for women.
\end{abstract}

Keywords: Coronary artery disease, Coronary artery bypass surgery, Quality of life, Euro Quality of life-5 Dimensions.

\section{Introduction}

Coronary artery disease (CAD) is considered the most prevalent heart diseases and the main cause of mortalities in the world today that affect patient's quality of life $(\mathrm{QOL})^{(1)}$. Reports on the prevalence or incidence of CAD in developing countries are very scarce, and routinely collected data 
is often incomplete and unreliable ${ }^{(2,3)}$. It is predicted that by 2020,25 million will be victims of cardiovascular diseases and they will be number-one cause of death and disability ${ }^{(4)}$. These diseases are responsible for various health complications for the patients and bring about considerable social costs In CAD patients, since the patients are facing decreased heart and physical capacity preceded by the ischemic heart attacks, their QOL is affected by these changes ${ }^{(5,6)}$.

In Egypt according to the latest WHO data published in April 2011, CAD deaths reached $21.73 \%$ of total deaths. The age adjusted death rate is 173.98 per 100,000 of population ranks Egypt 33 in the world $^{(7)}$. Treatment of CAD is aimed at managing symptoms, improve patients lifestyle, stopping or slowing the progression of the disease, and reduce the risk of heart attack and stroke $^{(8,9)}$. Advances in diagnosis, medical management, surgical and anesthesia techniques and cardiopulmonary bypass (CPB) have helped make surgery a viable treatment option for patients with cardiac disease $^{(10)}$.The method of treatment is based on many factors that are determined by patients symptoms, physical examination and diagnostic testing ${ }^{(11)}$.

The management of CAD encompasses lifestyle modification, control of CAD risk factors, evidence-based pharmacological therapy, patient education and revascularization ${ }^{(12)}$. Revascularization which includes percutaneous coronary intervention (PCI) or Coronary artery bypass grafting $(\mathrm{CABG})$ will be the second line of treatment ${ }^{(13)}$. The goals of this procedure are to relieve symptoms of coronary artery disease, enable the patient to resume a normal lifestyle, to lower the risk of a heart attack or other heart problems and to improve patient's quality of life $(\mathrm{QOL})^{(14)}$.

The concept of quality of life broadly encompasses how an individual measures the 'goodness' of multiple aspects of their life. These evaluations include one's emotional reactions to life occurrences, sense of life fulfillment and satisfaction with work and personal relationships ${ }^{(15)}$.
QOL had been described by WHO as "individuals' perception of their position in life in the context of the culture and value systems in which they live and in relation to their goals expectations, standards and concerns"(16). In addition that quality of life's specific domains and dimensions vary in relative importance among individuals, in part depending on their social and cultural background. However, five domains; physical, psychological, social, economic and spiritual are commonly regarded as relevant to quality of life ${ }^{(17)}$.

Improvement in QoL after CABG surgery differed according to subject gender, despite the fact that QoL domain scores were similar for men and women prior to surgery ${ }^{(18)}$. In a study of comparison of health related quality of life outcomes of men and women after coronary artery bypass surgery, it has been reported that women undergoing CABG surgery have a worse medical condition and fewer social and financial resources than $\operatorname{men}^{(19)}$. Moreover other studies have found that women appear to have more urgent or emergent presentations, tend to be older on presentation, have multiple co-morbidities (diabetes, hypertension, obesity and depression) when compared with men and recover less well than men after $\mathrm{CABG}^{(18,20)}$.

A quality of life approach works to ensure that the level of the well-being of people remains high despite the possibility of increasing number of people with disabilities or declining abilities. Consequently, the main focus is to maintain adequate level of functioning and high enjoyment of life in areas that an individual thinks are important for as long as possible. This is the primary goal of quality of life for the population as a whole ${ }^{(21)}$. The patient undergoing $\mathrm{CABG}$ surgery deserves to have confidence that the professional nurse is knowledgeable, caring, efficient, and effective in providing necessary perioperative care. Cardiac surgery is not the cure for coronary artery disease. It gives the patient the opportunity to make needed lifestyle adjustments and achieve the 
highest degree of health possible. Nurses are a part of the team that makes this return to health a possibility for the patient ${ }^{(22)}$.

\section{Aim of the Study}

The present study aimed to identify the relation between quality of life and sex of patients post coronary artery bypass surgery.

\section{Research Question}

Is there difference in quality of life between male and female patients post coronary artery bypass surgery?

\section{Materials and Method}

\section{Materials}

Design: A descriptive comparative design was used in this study.

Setting: This study was conducted at the open heart outpatient clinic (male \& female) at Alexandria Main University Hospital and Shark El Medina Hospital.

Subjects: A convenience sample of 160 adult patients underwent coronary artery bypass surgery were included in the study according to the following criteria: Age between (21-60) years old - Free from chronic diseases included; Diabetes mellitus, rheumatoid arthritis, malnutrition, hepatic disorders and renal failure. Statistical program Epi-Info. was used to estimate the sample size.

\section{Tool:}

\section{Tool I: Quality of Life of Adult Patients} Post Coronary Artery Bypass Surgery

One tool was used by the researcher to collect the data. It was divided into two parts:
Part I: Socio-demographic data sheet of post coronary artery bypass surgery patients:

It comprised of the patient's age, sex, residence, marital status, level of education, occupation and social \& economic status.

Part II: Euro Quality of Life-5 Dimensions (EQ-5D) structure interview questionnaire:

This tool was developed by Euro QOL group (1990) to assess QOL and modified by Euro QOL group (2005). It consisted of two elements:

A- The EQ-5D-5 level structure interview schedule: It comprises the following 5 dimensions:

1. Mobility: (The ability of the patient to move in comparison with before the surgery).

2. Self-care: (The ability of the patient to wash or dress him or herself).

3. Usual activities: (The ability of the patient to return to previous activities as work, study, housework, family or leisure activities).

4. Pain/discomfort: (Degree of pain or discomfort feeling).

5. Anxiety/depression: (Degree of anxiety or depression).

The five dimensions have five levels: No problems, slight or mild problems, moderate problems, severe problems, and extreme problems. All questions are scored negatively (5-1), (5) indicated lower quality of life and (1) indicated higher quality of life). Thus, the negatively framed questions should be reversed and transformed to positively framed questions such as $(1=5)$, $(2=4),(3=3)$, and $(4=2)(5=1)$ before data coding.

\section{B - Visual Analogue Scale (VAS):}

The EQ VAS records the respondent's self-rated health on a $20 \mathrm{~cm}$ vertical (0100). It will be used to assess health status of the patients with endpoints labeled 'the 
best health you can imagine 100' and 'the worst health you can imagine 0 .

\section{Method}

- An official letter from the Faculty of Nursing was submitted to the general director of both, the Alexandria Main University and Shark El medina Hospitals. A written approval to carry out the study was obtained from the directors of the chosen settings after explanation of the purpose of the study.

- The tools were employed to collect the present study data. Tool was developed by Euro QOL group (1990) to assess QOL and modified by Euro QOL group (2005), translation and validity was done by them also.

- The overall reliability of the tool "Euro Quality of life -5Dimentions" was tested using $(\alpha)$ Cronbach test on a sample of 16 subjects and found to be (0.82).

- The pilot study was conducted on 8 patients out of the sample selected conveniently to check and ensure clarity, applicability, and feasibility of the tools. The pilot study revealed that patient's health improvement increased by the time which improve QOL (patient's QOL post15 days equal $30 \%$, post 45 days equal $65 \%$ and post 90 days equal $90 \%$ ) So, 80 of the subjects were interviewed one month and half after surgery and another different 80 of the patients were interviewed after three months postoperatively) to illustrate the relation between length of postoperative and QOL improvement.

- After the approval of ethical research committee was obtained; the data collection was initiated covering a period of eight months (from May 2014 to January 2015).

- The total subjects consisted of 160 adult patients post CABG. All patients met the included criteria of subjects' selection in the study.
- Sociodemographic data, Euro quality of life five dimensions questions and VAS were collected from every patient who underwent CAGB and willing to participate in the study.

- The interview was conducted individually in the waiting room in the out-patient clinic (male \& female) twice (post one month and half and post three months postoperatively) while ensuring privacy.

- Every patient was asked to answer the questions honestly. The interview took 20- 30 minutes on an individual basis to be filled depending on the degree of understanding and response of the patient.

\section{Ethical considerations:}

- Written informed patients' consent will be obtained before data collection and after explanation of the study aim.

- Privacy of the patients was assured and confidentiality of the collected data was maintained.

\section{Statistical Analysis}

After completion of data collection, it was coded and transferred into a specially designed format so as to be suitable for computer feeding. Following data entry, checking and verification processes were carried out to avoid errors during data entry Statistical package for Social Sciences (SPSS) version 18 for windows was used for data analysis.

\section{Results}

Table (1) illustrates frequency distribution of study patients in relation to socio-demographic characteristics. Regarding patient's age, the results revealed that nearly half $(49 \%)$ of the patients are in the age group 50 to less than or equal 60 years old. In relation to sex, $51 \%$ of the patients were male, while $49 \%$ of them were female .More than two thirds $(75 \%)$ of patients are living in urban area, and more 
than one third of them $(31 \%)$ are illiterate. In relation to marital status $85 \%$ of the study subjects were married. Considering occupation, it was found that $(30 \%, 29 \%)$ of patients are house wife, and have manual work. Concerning economic status, the highest percent $(62.5 \%)$ of patients have enough family income per month. In relation to the determinant length of period postoperatively, $(50 \%)$ of the patients are post one month and half, and other post three months.

Table (2) presents distribution of the study patients in relation to Euro Quality of life-5 Dimensions (EQ-5D) Questionnaire values per percentage post one month and half and post three months. This table illustrates that in relation to mobility dimension, more than half of the patients $(68.5 \%)$ had slightly problems with mobility post one month, while $(96 \%)$ of them had no problem after three months. Regarding self-care dimensions, (50\%) of the study sample had slightly problems in performing their self-care activities after one month and half, but after three months vast majority $(92.5 \%)$ had no problems in performing their self-care .After one month and half $(55 \%)$ of the patients had moderate problems in performing their usual activities, while vast majority of them $(66.5 \%)$ had slightly problem. Concerning feelings of pain, the results concluded that $(55 \%)$ of the patients had slightly pain after one month and half as compared to (69\%) of them had slightly pain after three months. In relation to feeling of anxiety or depression after surgery, it was noted that $(37.5 \%, 70 \%)$ of the patients had no anxiety after one month and half and after three months post-surgery. From previous data it was obvious that there were improvement in all dimensions values per percentage post three months than post one month and half.

Table (3) represents that there is a high statistical significant relation between age and overall average score of EQ-5D. As the age study patients is significantly associated with overall average score for mobility, self-care, usual activities, pain/discomfort and anxiety/depression as $\mathrm{F}=3.479$
$(* \mathrm{P}=0.017), \mathrm{F}=7.977 \quad(* \mathrm{P}=0.00), \mathrm{F}=8.532$ $(* \mathrm{P}=0.00), \quad \mathrm{F}=2.986 \quad(* \mathrm{P}=0.033) \quad$ and $\mathrm{F}=3.196(* \mathrm{P}=0.025)$ respectively. On the other hand, it can observed that the young patients who are between 30-40 years have lower mean and lower quality of life to these domains as compared to other age group (3.6522 \pm 0.59457$)$.

Table (4) shows that there is a high statistical significant relation between sex and overall average score of EQ-5D and EQ VAS as $\mathrm{t}=4.378$ and $\mathrm{t}=4.696(\mathrm{P}=0.002 *)$ and $\left(\mathrm{P}=0.005^{*}\right)$. As the sex of study patients is significantly associated with average score for mobility, self-care and usual activities as $\mathrm{t}=2.381(* \mathrm{P}=0.000), \mathrm{t}=3.659$ $(* \mathrm{P}=0.000), \quad \mathrm{t}=3.809 \quad(* \mathrm{P}=0.007)$ respectively. Also, It can be observed that females have lower mean score and lower quality of life related to these dimension as compared with male $(4.46 \pm 0.636$, $4.14 \pm 0.944,3.14 \pm 1.009)$ respectively.

Table (5) demonstrates that there is no statistical significant relation between residence and overall average score for EQ5D. While the residence of the study patients is significantly associated with difference in mean scores for usual activities, pain/discomfort and anxiety/depression of EQ-5D as $\mathrm{t}=2.077$ $\left(\begin{array}{lll}* \mathrm{P}=0.001), \quad \mathrm{t}=0.840 & \left(0.040^{*}\right) \quad \mathrm{t}=1.011\end{array}\right.$ $\left({ }^{*} \mathrm{p}=0.021\right)$. It can be observed that patients coming from rural areas have lower mean score and lower quality of life related to these domains as compared with patients coming from urban areas (3.15 \pm 0.736 , $4.18 \pm 1.107)$. On the other hand, the table illustrates that the residence of the study patients is significantly associated with difference in pain/discomfort dimension scores as $\mathrm{t}=0.840\left({ }^{*} \mathrm{p}=0.040\right)$, so it can be observed that patients coming from rural areas have higher mean score and higher quality of life related to these dimension as compared with patients coming from urban areas $(3.95 \pm 0.552)$.

Table (6) Shows that there is a high statistical significant relation between level of education and overall average score for EQ-5D. As the level of education of study patients is significantly associated with the 
difference in average score for mobility, usual activities and anxiety /depression as $\mathrm{F}=2.204(* \mathrm{P}=0.057), \mathrm{F}=3.782(* \mathrm{P}=0.003)$, $\mathrm{F}=2.251 \quad(* \mathrm{P}=0.052)$. Also, it can be observed that patients who are illiterate and elementary have lower mean score and lower quality of life as compared with other educational level $\quad(4.0360 \pm 0.0 .65489$, $3.9611 \pm 0.51452)$.

Table (7) from the table it can be seen that there is a high statistical significant relation between occupation and overall average score for EQ-5D as $\mathrm{F}=4.061$ $(* \mathrm{P}=0.004)$. It can be observed that patients who housewives have lower mean score and lower quality of life related to overall domains of EQ-5D as compared with other patients $(3.8625 \pm 0.71597)$.

Table (8) it can be seen that there is no statistical significant relation between monthly income and overall average score for EQ-5D. On the other hand, the monthly income of the study patients is significantly associated with difference in dimension scores of mobility, self-care, usual activities and pain/discomfort dimensions as $\mathrm{t}=7.834$ $(* \mathrm{P}=0.006), \mathrm{t}=9.775(* \mathrm{P}=0.002), \mathrm{t}=10.803$ (*P=0.001), $\mathrm{t}=6.554(* \mathrm{P}=0.011)$, It can be observed that insufficient monthly income patients have lower mean score and lower quality of life related to these dimensions as compared to sufficient monthly income patients $(4.0267 \pm 0.63935)$.

Table (9) denoted that there is a high statistical significant relation between overall average score for EQ-5D and EQ VAS and determinant length period Postoperatively as $\mathrm{t}=17.430$ and $\mathrm{t}=17.282$ $\left(\mathrm{P}=0.000^{*}\right.$ and $\left.\mathrm{P}=0.000^{*}\right)$. The determinant length period Postoperatively of the study patients is significantly associated with difference in dimension scores of mobility, self-care, usual activities pain/discomfort, anxiety/depression dimensions as $\mathrm{t}=12.527$ $\left(\mathrm{P}=0.000^{*}\right), \mathrm{t}=11.846\left(\mathrm{P}=0.000^{*}\right), \mathrm{t}=17.219$ $\left(\mathrm{P}=0.050^{*}\right), \mathrm{t}=8.454\left(\mathrm{P}=0.003^{*}\right), \mathrm{t}=5.531$ $(\mathrm{P}=0.000 *)$, Moreover group2 have higher mean score and higher quality of life related to these dimensions as compared to group1

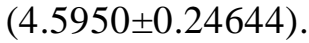

Figure (1) demonstrates that there was a high statistical significant relation between overall average score of EQ-5D for patient sex and determinant length of postoperative period. It can be observed that group 2 male patients had a higher mean score and higher quality of life as compared to group 1 male patients. Regarding group 2 female patients had higher mean score and higher quality of life as compared to group 1 female patients.

Figure (2) concludes that there was a high statistical significant relation between overall average score of EQ-5D for sex as male patients have higher mean score and higher quality of life as compared with female patients.

Figure (3) proves that there was a high statistical significant relation between EQVAS and sex; as male patients had higher mean score and higher quality of life related as compared with female patients.

Table (10) shows the Multivariate analysis stepwise regression for 5 Dimensions: From this table it can be seen that the most effective factors that affect mobility post CABG were postoperative period and patient's occupation as $\mathrm{F}=(13.529,4.151) \quad \mathrm{P}=\left(0.001^{*}, 0.001^{*}\right)$, also there were positive relation between postoperative period and mobility as $\mathrm{B}=0.828$, and negative relation between occupation (house wife) and mobility as $\mathrm{B}=-0.277$. Also the most effective factors that affect self-care post CABG were postoperative period and patient's sex as $\mathrm{F}=(12.926,5.401) \mathrm{P}=(0.001 *, 0.001 *)$, in addition, there were positive relation between postoperative period and self-care as $\mathrm{B}=1.118$, and negative relation between sex (women) and self-care as $\mathrm{B}=-0.467$. The most effective factors that affect usual activities post CABG were postoperative period, patient's sex, occupation and age as $\mathrm{F}=(21.106,7.217,2.969,2.124) \mathrm{P}=(0.001 *$, $\left.0.001^{*}, 0.003^{*}, 0.035^{*}\right)$, also there were positive relation between postoperative period and occupation(not work) and usual activities as $\mathrm{B}=1.579,0.307$ and negative relation between sex (women) and age and usual activities as $\mathrm{B}=-0.587,-0.099$. In addition, the most effective factors that 
affect pain post $\mathrm{CABG}$ were postoperative period and patient's sex as $\mathrm{F}=(8.924,4.127)$ $\mathrm{P}=(0.001 *, 0.001 *)$. On the other hand, there were positive relation between postoperative period and pain as $\mathrm{B}=0.729$, and negative relation between sex (women) and pain as $\mathrm{B}=-0.337$. The most effective factors that affect anxiety/depression post CABG were postoperative period and occupation (house wife and not work) as $\mathrm{F}=(6.747,4.779,2.110) \mathrm{P}=\left(0.001^{*}, 0.001^{*}\right.$, $0.036 *)$. Also there were positive relation between postoperative period and occupation (not work) and anxiety/depression as $\mathrm{B}=0.808,0.356$ and negative relation between occupation (house wife) and anxiety/depression as $\mathrm{B}=-0.651$.

\section{Discussion}

Nowadays, Coronary Artery Diseases (CAD) became a big health problem and it is one of the main causes of mortality in the world. It is estimated that coronary artery diseases are going to be at the top of fifteen causes of global diseases ${ }^{(23)}$. This disease does not only influence patients' health, but also social relationships, life pattern, family atmosphere, occupation and income levels ${ }^{(24)}$.

Regarding mobility, the present study had showed that this dimension was the greatest improvement dimension in between all dimensions as after one month and half ; more than two third of patients reported that they have only slight problem with mobility but after three months vast majority of the patients reported that they didn't have any problem with mobility. Similar results mentioned by Yuk $(2005)^{(9)}$ who reported that there were significant higher levels of self-efficacy expectation and self-reported activity for general activities, walking, and climbing stairs four weeks after surgery, and added that these levels were improved much better two months after surgery. Kerestes $(2003)^{(25)}$ stated that the most improved score that occurred in the general health perception and physical functioning was after three months post-surgery. These findings were contradicted with another study concluded that patients had inappropriate quality of life three months after surgery due to patient's post-surgery anxiety regarding prognosis, duration of hospital stay and hospital expenses ${ }^{(26)}$.

Concerning self-care, the present study had illustrated that the improvement in this dimension was also obvious during both one month and half and three months. More than two third of patients their QOL in relation to self-care ranged from slight to moderate problems after one month and half from surgery, but after three months vast majority of patients reported that they didn't have any problem with self-care. These results might return to complete wound healing, adaptation with new life's condition and decrease level of pain after three months. These findings were in line with Kołtowski et al $(2011)^{(27)}$ and Kerestes $(2003)^{(25)}$ who stated that self-care improved after one month of surgery and this improvement increased post three months of surgery. On the other hand, Rahimi et al. (2014) $)^{(28)}$ found that the quality of life of the patients in emotional, physical and social dimensions had decreased before surgery due to occurrence of depression after CABG.

Regarding usual activities, the findings found that after one month and half the majority of patients' QOL regarding usual activities were ranged from moderate to severe problems. In contrast after three months, majority of them their QOL regarding usual activities ranged from no to slight problems. Less improvement post one month and half was occurred, this might be returned to the fact that the dimensions include work, study, housework, family or leisure activities need more effort to be performed. In addition to incomplete sternum bone healing which needs three months to achieve complete healing. These results were supported by Mullany $(2003)^{(29)}$ who found that performing usual activities will depend on rate of recovery, as well as the physical and emotional demands of patient' activities, and added that relatively sedentary activities will need from 4 to 6 weeks after the operation while 
heavy manual activity will need 12 weeks to be performed.

On the other hand, different physiological and psychological patient' problems basically were due to fear, anxiety and immobility; so consequently health related quality of life will be distorted in these patients and made them unable to resume their usual activities ${ }^{(30,31)}$.

Pain is one of the most prevalent symptoms identified by people after CABG surgery, both in-hospital and after discharge .The present study findings indicated that after one month and half the majority of patients 'feeling of pain was ranged from slight to moderate, while the remainders their feeling of pain was severe, however after three months vast majority of patients ' feeling of pain ranged from no pain to slight pain, while the remainders their feeling of pain was moderate. These findings were in line with Tranmer and Parry $(2004)^{(32)}$ who reported that more than half of patients continued to have pain at 6 weeks after CABG surgery. Another study indicated that unrelieved pain can be problematic and can persist for approximately 8 weeks in half of patients following home discharge after CABG surgery $^{(33)}$.

Regarding anxiety, the present study showed that after one month and half more than half of patients their level of anxiety ranged from slight to moderate level, while after three months the majority of patient' feeling of anxiety ranged from no to slight level of anxiety. Similar results were in line with these results ${ }^{(34)}$. Moreover, Tully and Baker $(2012)^{(35)}$ found that up to $50 \%$ of patients experience symptoms of depression one month post CABG and added that lower level of depression symptoms were after surgery that may reflect the upturn in mood associated with improvements in physical condition from revascularization.

However, these results contradicted the results of McCrone et al $(2001)^{(36)}$ indicated that younger patients and women were more prone to depression within the first several days and weeks after CABG and was elevated 12 weeks after CABG. Studzińska et al (2006) ${ }^{(37)}$ also pointed out to that more frequent occurrence of depression was after myocardial revascularization. Another study found that the majority of patients were diagnosed with incidental depression and only the minority of them suffered from chronic depression $^{(38)}$.

Concerning the correlation between age and quality of life's dimensions, there was a high statistical significant relation between age and overall average score of EQ-5D.These findings were supported by Markou et al. (2008) ${ }^{(39)}$ and Baig et al. $(2013)^{(40)}$ who stated that there was a relationship between age and perceived quality of life after the operation. Performing CABG in the elderly may be associated with significant improvements in health related quality of life. In contrast to Koltowski et al. $(2011)^{(27)}$ and Irfan et al. $(2013)^{(41)}$ stated that the association between age and all QOL' domains (physical, pain, general health, vitality, social functioning, emotional and mental health) were statistically not significant. Moreover, the two authors reported that there was a relationship between age and perceived quality of life after the operation, but the younger patients not only had a higher baseline QOL, but their perceived QoL also tended to improve more quickly. In contrast, the older patients tended to report lower Visual Analogue Scale values, and their score on the sixth day after CABG was $20 \%$ lower than the pre-operative one. The cause of this observation remains uncertain, but Maggioni et al. (2010) ${ }^{(42)}$ in their study found that the younger age groups suffer from less comorbidity, which might explain the higher pre-surgical Visual Analogue Scale scores.

The outcomes for women after CABG are different from those of men ${ }^{(18)}$. In fact, earlier studies comparing the outcomes of myocardial revascularization between genders had shown that women required longer ICU stays, longer postoperative care, longer mechanical ventilation, and longer hospital stay. In addition, another explanation for the gender differences in QoL post CABG is the timing of operation 
for women as they attend to surgery in old age with worse overall health status. Women in this age cohort present with several psychosocial risk factors: They have higher levels of depression, are less educated, and have less social support. Norris et al $(2008)^{(43)}$ and Nogueira et al. $(2008)^{(44)}$ found that women with coronary artery disease report worse QOL after CABG when compared with men. These findings were consistent with the present results which concluded that there was a high statistical significant relation between sex and overall average score of EQ-5D, in which men achieved more improvement than women after CABG

On the other hand, Hunt et al. $(2000)^{(45)}$ and Kaur et al. $(2013)^{(46)}$ in their study of comparing quality of life and lifestyle of patients before and after CABG reported that gender had no significant association with quality of life after CABG.

The findings of the current study revealed that all men's quality of life dimensions were improved especially pain and anxiety in comparison with women who achieved less improvement in pain and anxiety. These findings were in line with Douki et al. (2011) ${ }^{(47)}$ findings who reported that women had significantly higher anxiety scores than men preoperatively. Nevertheless these results contradict the results of Nogueira et al. $(2008)^{(44)}$ who found that according to gender, the scores for pain, general health emotional problems, and mental health were found to be similar.

There is no debit that education has greatest effect on quality of life. As the correlation between level of education and quality of life dimensions, there was a high statistical significant relation between level of education and overall average score of EQ-5D. These findings are supported by HOS et al. (2010) $)^{(48)}$ who stated that education levels showed significant difference with the quality of life dimensions, as respondents with tertiary education possessed the highest score and higher quality of life followed by primary education .This can be explained through the fact that educated person maintains their life style and health related behavior than the poorly educated person. On the other hand, the findings disagree with Sabzmakan et al. $(2010)^{(49)}$ who stated that no statistically significant difference between level of education and quality of life post CABG.

The present study has indicated that there was a high statistical significant relation between occupation and overall average score of EQ-5D.As housewife and professional work had the lower quality of life in relation to overall domains of EQ-5D as compared with other patients' occupation. The findings agreed with another studies that reported that there was significant relation between occupation and QOL and the prevalence of coronary artery diseases was more among people who had less physical activities, as physical activities can provide the chance for decreasing low density lipoprotein in the blood ${ }^{(41,50)}$. In contrast, the findings disagree with Sabzmakan et al. (2010) ${ }^{(49)}$ who stated that no statistically significant difference between occupation and quality of life post CABG and added that there were other factors as educational program that affect QOL rather than occupation.

QOL outcomes had become a major focus for $\mathrm{CABG}$, common and effective treatment for coronary artery disease. QOL significantly contributes to understanding patients' perceptions of outcomes attributable to this surgery. Previous researches on patient outcomes for CABG had included that the evaluation of changes in QOL at intervals of 3-6 months postsurgery. There was a lack of researches that evaluate patient outcomes before 3 months, so there was a need for measuring patients' QOL before and during three months ${ }^{(51)}$.

In relation to the determinant length period postoperatively, the present study had indicated that there was a high statistical significant relation between overall average score for EQ-5D and EQ VAS and determinant length period postoperatively. Although there were improvement in two groups, quality of life 
of patients post three months was better than quality of life of patients post one month and half. This improvement appeared in all dimensions especially pain and usual activities dimensions which their improvement were obvious three months postoperatively than one month and half postoperatively. This might be due to incomplete wound healing, fear of pain, and lack of adaptation with new condition post CABG. These findings are supported by study stated that quality of life was improved 3 months post $\mathrm{CABG}^{(25)}$. On the other hand , Rahimi et al. (2014) ${ }^{(28)}$ reported that quality of life was measured two months after CABG and the results of their study indicated that there was decrease in quality of life of the patients in the three emotional, physical and social dimensions and the total quality of life.

The main findings of the present study were coming up from the multivariate analysis, where the given variables (age, sex, occupation, postoperative period) were tested on their influence on potential improvement of QOL after CABG. The multivariate analysis had demonstrated that the previous factors affect all dimensions but sex and postoperative period were the most effective factors. These findings were in line with Norris et al. (2008) ${ }^{(43)}$.Also, Nogueira et al. $(2008)^{(44)}$ found that the patient's sex was the most effective factor affect patient's QOL post CABG. In addition to Dueoas et al. $(2012)^{(52)}$ in their study who measured patients' QOL after three different period (immediate, three months and six months post CABG) concluded that postoperative period was the most important factor that should be taken into consideration during measuring QOL post CABG .

In contrast, Okkonen and Vanhanen $(2006)^{(53)}$ found that low social support, low level of education, the occurrence of at least one stressful situation within a year before the surgery, limited access to medical care, and prolonged intensive care after the surgery were the most significant factors that affect patients' QOL after
CABG. Little support provided by family members during perioperative period and living in one-person household also increases the incidence of depression after surgical revascularization.

It is necessary for the nurse to know the existing quality of life of patients to plan interventions towards improving quality of life of the patients. Moreover, developing intervention for CABG patients, management of complications, individualized care, sexual counseling, support group and family care should also be considered ${ }^{(54)}$.

\section{Conclusion}

Based on the findings of the present study, it can be concluded that CABG surgery improves patients' QOL. Sex and determinant length period postoperatively are considered factors affecting patients' QOL post CABG more than any other factors. Men achieved more improvement than women. Women are more likely to report moderate to severe pain after $\mathrm{CABG}$ that interferes with movement, walking and usual activities. Moreover; prevalence of depression among female patients after CABG was more noticed than male. Patient's QOL post three months was better than patient's QOL post one month and half.

\section{Recommendations}

- Patient and family should be provided with information and practice pre and post-surgery through videos, models and printed materials.

- All patients should be involved in cardiac rehabilitation program and should be initiated as early as possible to enhance recovery and improve patient's health. 
Quality of Life and Sex of Patients Post Coronary Artery Bypass Surgery

- Nurses should attend update conferences and in-service training program/or workshops, about CABG surgery and patients' needs post-surgery.
- Standards of care and guidelines should be developed to improve the patient's quality of life post CABG especially for women. 
Table (1): Frequency distribution of study patients in relation to socio-demographic characteristics $\mathrm{No}=(\mathbf{1 6 0})$

\begin{tabular}{|c|c|c|c|}
\hline \multicolumn{4}{|c|}{ "Sociodemographic Characteristics } \\
\hline Items & No & $\%$ & Total \\
\hline $\begin{array}{l}\text { Age (years): } \\
20- \\
30- \\
40- \\
50-60\end{array}$ & $\begin{array}{c}7 \\
23 \\
52 \\
78\end{array}$ & $\begin{array}{c}4.5 \\
14.00 \\
32.5 \\
49.00\end{array}$ & 160 \\
\hline $\begin{array}{l}\text { Sex: } \\
\text { Male } \\
\text { Female }\end{array}$ & $\begin{array}{l}81 \\
79\end{array}$ & $\begin{array}{l}51.00 \\
49.00\end{array}$ & 160 \\
\hline $\begin{array}{l}\text { Place of resident } \\
\text { Rural } \\
\text { Urban }\end{array}$ & $\begin{array}{c}40 \\
120\end{array}$ & $\begin{array}{l}25.00 \\
75.00\end{array}$ & 160 \\
\hline $\begin{array}{l}\text { Marital status } \\
\text { Single } \\
\text { Married } \\
\text { Widow }\end{array}$ & $\begin{array}{c}12 \\
137 \\
11\end{array}$ & $\begin{array}{l}7.5 \\
85.5 \\
7.00 \\
\end{array}$ & 160 \\
\hline $\begin{array}{l}\text { Education level } \\
\text { Illiterate } \\
\text { Primary } \\
\text { Preparatory } \\
\text { Secondary } \\
\text { University }\end{array}$ & $\begin{array}{c}50 \\
35 \\
23 \\
2 \\
14\end{array}$ & $\begin{array}{c}31.00 \\
44.00 \\
14.5 \\
1.00 \\
9.00\end{array}$ & 160 \\
\hline $\begin{array}{l}\text { Job } \\
\text { Administrative work } \\
\text { Manual work } \\
\text { House wife } \\
\text { Not worker } \\
\text { Others } \\
\end{array}$ & $\begin{array}{c}37 \\
46 \\
48 \\
26 \\
3\end{array}$ & $\begin{array}{c}23.00 \\
29.00 \\
30.00 \\
16.00 \\
2.00 \\
\end{array}$ & 160 \\
\hline $\begin{array}{l}\text { Monthly income } \\
\text { Less than enough } \\
\text { Enough }\end{array}$ & $\begin{array}{c}60 \\
100 \\
\end{array}$ & $\begin{array}{l}37.5 \\
62.5 \\
\end{array}$ & 160 \\
\hline $\begin{array}{l}\text { Determinant length of period Postoperative. } \\
\text { Month and half ( } 45 \text { days). } \\
\text { Three months ( } 90 \text { days). }\end{array}$ & $\begin{array}{l}80 \\
80\end{array}$ & $\begin{array}{l}50.00 \\
50.00\end{array}$ & 160 \\
\hline
\end{tabular}


Quality of Life and Sex of Patients Post Coronary Artery Bypass Surgery

Table (2): Frequency distribution of the study patients in relation to Euro Quality of Life-5 Dimensions (EQ-5D) questionnaire values per percentage

\begin{tabular}{|c|c|c|c|c|c|c|c|c|c|c|c|c|c|c|c|c|c|c|c|}
\hline \multirow{3}{*}{ Dimensions } & \multicolumn{11}{|c|}{ Post one month and half (G1) } & \multicolumn{6}{|c|}{ Post three months (G2) } & \multirow{2}{*}{\multicolumn{2}{|c|}{ Total }} \\
\hline & \multicolumn{2}{|c|}{$\begin{array}{c}\mathrm{N}_{0} \\
\text { problem }\end{array}$} & \multicolumn{2}{|c|}{ Slightly } & \multicolumn{2}{|c|}{ Moderate } & \multicolumn{2}{|c|}{ Severe } & \multicolumn{3}{|c|}{ Extremely } & \multicolumn{2}{|c|}{$\begin{array}{c}\mathrm{N}_{0} \\
\text { problem }\end{array}$} & \multicolumn{2}{|c|}{ Slightly } & \multicolumn{2}{|c|}{ Moderate } & & \\
\hline & No & $\%$ & $\mathrm{~N}_{0}$ & $\%$ & No & $\%$ & No & & & No & $\%$ & $\mathrm{~N}_{0}$ & $\%$ & $\mathrm{~N}_{0}$ & $\%$ & $\mathrm{~N}_{0}$ & $\%$ & $\mathrm{~N}_{0}$ & $\%$ \\
\hline Mobility & 19 & 23.5 & 55 & 68.5 & 6 & 8 & - & & & 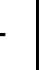 & $\begin{array}{ll}- \\
-\end{array}$ & 77 & 96 & 3 & 4 & 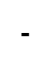 & - & 160 & 100 \\
\hline Self-Care & 15 & 19 & 39 & 50 & 22 & 27 & 4 & & & 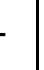 & - & 74 & 92.5 & 6 & 7.5 & & - & 160 & 100 \\
\hline Usual Activities & - & - & 4 & 5 & 44 & 55 & 32 & & & 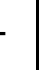 & - & 21 & 26 & 53 & 66.5 & 6 & 7.5 & 160 & 100 \\
\hline Pain/Discomfort & - & - & 44 & 55 & 33 & 41 & 3 & & & 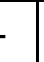 & - & 22 & 27 & 55 & 69 & 3 & 4 & 160 & 100 \\
\hline Anxiety/Depression & 30 & 37.5 & 23 & 29 & 21 & 26 & 4 & & & 2 & 2.5 & 56 & 70 & 21 & 26 & 3 & 4 & 160 & 100 \\
\hline
\end{tabular}


Quality of Life and Sex of Patients Post Coronary Artery Bypass Surgery

Table (3): Relation between Euro Quality of Life-5 Dimensions (EQ-5D) and sociodemographic data of study patients related to age

\begin{tabular}{|c|c|c|c|c|c|c|c|}
\hline \multirow{3}{*}{ Euro Q0L dimensions } & \multicolumn{5}{|c|}{ Age } & \multirow{3}{*}{$\mathrm{F}$} & \multirow{3}{*}{$\begin{array}{l}\text { Test of } \\
\text { significanc } \\
\mathrm{e}\end{array}$} \\
\hline & 20- $(\mathrm{N}=7)$ & 30. $(\mathrm{N}=23)$ & 40- $(\mathrm{N}=52)$ & $50-60(\mathrm{~N}=78)$ & Total $(\mathrm{N}=160)$ & & \\
\hline & MeantSD & MeantSD & MeantSD & Mean \pm SD & MeantSD & & \\
\hline $\begin{array}{l}\text { Average score for } \\
\text { mobility. }\end{array}$ & $4.57 \pm 0.535$ & $4.22 \pm 0.671$ & $4.62 \pm 0.491$ & $4.63 \pm 0.561$ & $4.56 \pm 0.568$ & 3.479 & $0.017^{*}$ \\
\hline $\begin{array}{l}\text { Average score for self- } \\
\text { care. }\end{array}$ & $4.57 \pm 0.535$ & $3.65 \pm 0.885$ & $4.44 \pm 0.916$ & $4.51 \pm 0.619$ & $4.37 \pm 0.814$ & 7.977 & $0.000^{*}$ \\
\hline $\begin{array}{l}\text { Average score for usual } \\
\text { activities. }\end{array}$ & $4.14 \pm 1.089$ & $2.61 \pm 0.941$ & $3.58 \pm 0.637$ & $3.49 \pm 1.003$ & $3.42 \pm 0.955$ & 8.532 & $0.000^{*}$ \\
\hline $\begin{array}{l}\text { Average score } \\
\text { pain/discomfort. }\end{array}$ & $3.57 \pm 0.535$ & $3.57 \pm 0.728$ & $3.90 \pm 0.664$ & $3.97 \pm 0.602$ & $3.88 \pm 0.652$ & 2.986 & $0.033^{*}$ \\
\hline $\begin{array}{l}\text { Average score for } \\
\text { anxiety /depression. }\end{array}$ & $4.57 \pm 0.535$ & $4.22 \pm 0.951$ & $4.02 \pm 1.111$ & $4.49 \pm 0.698$ & $4.30 \pm 0.903$ & 3.196 & $0.025^{*}$ \\
\hline $\begin{array}{l}\text { Overall average scores } \\
\text { for (EQ-5D). }\end{array}$ & $4.2857 \pm 0.64143$ & $3.6522 \pm 0.59457$ & $4.1115 \pm 0.60119$ & $4.2179 \pm 0.55567$ & $4.1050 \pm 0.60603$ & 5.891 & $0.001^{*}$ \\
\hline
\end{tabular}

F: ANOVA test

$\left.{ }^{*}\right)$ statistically significant $(\mathrm{P}<0.05)$

SD: standard deviation

$\mathrm{N}$ : number 
Table (4): Relation between Euro Quality of Life-5 Dimensions (EQ-5D) and sociodemographic data of study patients related to sex

\begin{tabular}{|c|c|c|c|c|c|c|}
\hline \multirow{3}{*}{$\begin{array}{l}\text { Euro QOL } \\
\text { dimensions }\end{array}$} & \multicolumn{4}{|c|}{ Sex } & \multirow{3}{*}{$\mathbf{t}$} & \multirow{3}{*}{$\begin{array}{c}\text { Test of } \\
\text { significance }\end{array}$} \\
\hline & \multicolumn{2}{|c|}{ Male $(\mathrm{N}=81)$} & \multicolumn{2}{|c|}{ Female $(\mathrm{N}=79)$} & & \\
\hline & Mean & SD & Mean & SD & & \\
\hline $\begin{array}{l}\text { Average score for } \\
\text { mobility. }\end{array}$ & 4.67 & 0.474 & 4.46 & 0.636 & 2.381 & $0.000 *$ \\
\hline $\begin{array}{l}\text { Average score for } \\
\text { self-care. }\end{array}$ & 4.59 & 0.587 & 4.14 & 0.944 & 3.659 & $0.000 *$ \\
\hline $\begin{array}{l}\text { Average score for } \\
\text { usual activities. }\end{array}$ & 3.69 & 0.816 & 3.14 & 1.009 & 3.809 & $0.007 *$ \\
\hline $\begin{array}{l}\text { Average score } \\
\text { pain/discomfort. }\end{array}$ & 4.04 & 0.621 & 3.71 & 0.644 & 3.282 & 0.74 \\
\hline $\begin{array}{l}\text { Average score for } \\
\text { anxiety /depression. }\end{array}$ & 4.52 & 0.868 & 4.08 & 0.888 & 3.188 & 0.676 \\
\hline $\begin{array}{l}\text { Overall average } \\
\text { scores for(EQ VAS) }\end{array}$ & 4.0654 & 0.53500 & 3.6108 & 0.68260 & 4.696 & $0.005^{*}$ \\
\hline $\begin{array}{l}\text { Overall average } \\
\text { scores for (EQ-5D). }\end{array}$ & 4.3012 & 0.49206 & 3.9038 & 0.64757 & 4.378 & $0.002 *$ \\
\hline
\end{tabular}

t: t- test

$(*)$ : statistically significant $(\mathrm{P}<0.05)$

SD: standard deviation

$\mathrm{N}$ : number

Table (5): Relation between Euro Quality of Life-5 Dimensions (EQ-5D) and sociodemographic data of study patients related to residence

\begin{tabular}{|c|c|c|c|c|c|c|}
\hline \multirow{3}{*}{$\begin{array}{l}\text { Euro QOL } \\
\text { dimensions }\end{array}$} & \multicolumn{4}{|c|}{ Residence } & \multirow{3}{*}{$\mathbf{t}$} & \multirow{3}{*}{$\begin{array}{c}\text { Test of } \\
\text { significance }\end{array}$} \\
\hline & \multicolumn{2}{|c|}{ Urban $(\mathrm{N}=120)$} & \multicolumn{2}{|c|}{ Rural $(\mathrm{N}=40)$} & & \\
\hline & Mean & SD & Mean & SD & & \\
\hline $\begin{array}{l}\text { Average score for } \\
\text { mobility. }\end{array}$ & 4.56 & 0.547 & 4.58 & 0.636 & 0.160 & 0.344 \\
\hline $\begin{array}{l}\text { Average score for } \\
\text { self-care. }\end{array}$ & 4.41 & 0.815 & 4.25 & 0.809 & 1.066 & 0.769 \\
\hline $\begin{array}{l}\text { Average score for } \\
\text { usual activities. }\end{array}$ & 3.51 & 1.004 & 3.15 & 0.736 & 2.077 & $0.001 *$ \\
\hline $\begin{array}{l}\text { Average score } \\
\text { pain/discomfort. }\end{array}$ & 3.85 & 0.682 & 3.95 & 0.552 & 0.840 & $0.040 *$ \\
\hline $\begin{array}{l}\text { Average score for } \\
\text { anxiety /depression. }\end{array}$ & 4.34 & 0.825 & 4.18 & 1.107 & 1.011 & $0.021 *$ \\
\hline $\begin{array}{l}\text { Overall average } \\
\text { scores for (EQ-5D). }\end{array}$ & 4.1333 & 0.59822 & 4.0200 & 0.62888 & 1.024 & 0.849 \\
\hline
\end{tabular}

$\mathrm{t}=\mathrm{t}-$ test

(*): statistically significant $(\mathrm{P}<0.05)$.

SD: standard deviation.

$\mathrm{N}$ : number 
Quality of Life and Sex of Patients Post Coronary Artery Bypass Surgery

Table (6): Relation between Euro Quality of life-5 Dimentions (EQ-5D) and sociodemographic data of study patients related to level of education

\begin{tabular}{|c|c|c|c|c|c|c|c|c|c|}
\hline \multirow{3}{*}{ Euro Q0L dimensions } & \multicolumn{7}{|c|}{ Level of education } & \multirow{3}{*}{$\mathrm{F}$} & \multirow{3}{*}{$\begin{array}{c}\text { Test of } \\
\text { significance }\end{array}$} \\
\hline & $\begin{array}{c}\text { Illiterate } \\
(\mathrm{N}=50)\end{array}$ & $\begin{array}{c}\text { Read } \\
\text { \&Write } \\
(\mathrm{N}=35)\end{array}$ & $\begin{array}{c}\text { Elementary } \\
(\mathrm{N}=36)\end{array}$ & $\begin{array}{c}\text { Preparatory } \\
(\mathrm{N}=23)\end{array}$ & $\begin{array}{c}\text { Secondary } \\
(\mathrm{N}=2)\end{array}$ & $\begin{array}{c}\text { University } \\
(\mathrm{N}=14)\end{array}$ & $\begin{array}{c}\text { Total } \\
(\mathrm{N}=100)\end{array}$ & & \\
\hline & Mean \pm SD & Mean $\pm S D$ & Mean $\pm S D$ & MeantSD & Mean \pm SD & Mean \pm SD & Mean \pm SD & & \\
\hline $\begin{array}{l}\text { Average score for } \\
\text { mobility. }\end{array}$ & $4.60 \pm 0.606$ & $4.49 \pm 0.658$ & $4.39 \pm 0.494$ & $4.65 \pm 0.487$ & $4.50 \pm 0.707$ & $\begin{array}{l}4.93 \pm \\
0.267\end{array}$ & $\begin{array}{l}4.56 \pm \\
0.568\end{array}$ & 2.204 & $0.057^{*}$ \\
\hline $\begin{array}{l}\text { Average score for self- } \\
\text { care. }\end{array}$ & $4.24 \pm 1.021$ & $4.46 \pm 0.657$ & $4.22 \pm 0.760$ & $3.39 \pm 0.722$ & $5.00 \pm 0.000$ & $\begin{array}{l}4.86 \pm \\
0.363\end{array}$ & $\begin{array}{l}4.37 \pm \\
0.814\end{array}$ & 1.870 & 0.103 \\
\hline $\begin{array}{l}\text { Average score for usual } \\
\text { activities. }\end{array}$ & $3.38 \pm 0.830$ & $3.43 \pm 1.119$ & $3.22 \pm 0.866$ & $3.17 \pm 1.029$ & $4.00 \pm 0.000$ & $4.36 \pm 0.497$ & $3.42 \pm 0.955$ & 3.782 & $0.003^{*}$ \\
\hline $\begin{array}{l}\text { Average score } \\
\text { pain/discomfort. }\end{array}$ & $3.88 \pm 0.594$ & $3.89 \pm 0.796$ & $3.75 \pm 0.554$ & $3.83 \pm 0.717$ & $\begin{array}{l}4.50 \pm \\
0.707\end{array}$ & $4.14 \pm 0.535$ & $3.88 \pm 0.652$ & 1.140 & 0.342 \\
\hline $\begin{array}{l}\text { Average score for } \\
\text { anxiety /depression. }\end{array}$ & $4.08 \pm 0.966$ & $4.51 \pm 0.658$ & $4.22 \pm 1.098$ & $4.22 \pm 0.850$ & $\begin{array}{l}4.50 \pm \\
0.707\end{array}$ & $4.86 \pm 0.363$ & $4.30 \pm 0.903$ & 2.251 & $0.052 *$ \\
\hline Overall average scores & $4.0360 \pm 0.654$ & $4.1543 \pm 0.638$ & $3.9611 \pm 0.514$ & $4.0522 \pm 0.603$ & $4.5000 \pm 0.424$ & $4.6286 \pm 0.246$ & $4.1050 \pm 0.606$ & 3.063 & $0.012^{*}$ \\
\hline for (EQ-5D). & 89 & 17 & 52 & 68 & 26 & 29 & 03 & & \\
\hline
\end{tabular}

F: ANOVA test

(*) statistically significant $(\mathrm{P}<0.05)$

SD: standard deviation

$\mathrm{N}$ : number 
Quality of Life and Sex of Patients Post Coronary Artery Bypass Surgery

Table (7): Relation between Euro Quality of Life-5 Dimensions (EQ-5D) and sociodemographic data of study patients related to occupation

\begin{tabular}{|c|c|c|c|c|c|c|c|c|}
\hline \multirow{3}{*}{ Euro QOL dimensions } & \multicolumn{6}{|c|}{ Occupation } & \multirow{3}{*}{$\mathrm{F}$} & \multirow{3}{*}{$\begin{array}{c}\text { Test of } \\
\text { significance }\end{array}$} \\
\hline & $\begin{array}{l}\text { Professional } \\
\text { work (n=2) }\end{array}$ & $\begin{array}{c}\text { Manual work } \\
(\mathrm{N}=8)\end{array}$ & $\begin{array}{l}\text { House wife } \\
\qquad(\mathrm{N}=42)\end{array}$ & $\begin{array}{c}\text { Not working } \\
(\mathrm{N}=42)\end{array}$ & $\begin{array}{l}\text { Other } \\
(\mathrm{N}=6)\end{array}$ & $\begin{array}{l}\text { Total } \\
(\mathrm{N}=100)\end{array}$ & & \\
\hline & Mean $\pm S D$ & Mean $\pm S D$ & MeantSD & Mean $\pm S D$ & Mean $\pm S D$ & MeantSD & & \\
\hline $\begin{array}{l}\text { Average score for } \\
\text { mobility. }\end{array}$ & $4.59 \pm 0.498$ & $4.63 \pm 0.488$ & $4.44 \pm 0.712$ & $4.58 \pm 0.504$ & $5.00 \pm 0.00$ & $4.56 \pm 0.568$ & 3.479 & $0.017^{*}$ \\
\hline $\begin{array}{l}\text { Average score for self- } \\
\text { care. }\end{array}$ & $4.30 \pm 0.812$ & $4.57 \pm 0.583$ & $4.15 \pm 1.031$ & $4.46 \pm 0.647$ & $5.00 \pm 0.00$ & $4.37 \pm 0.814$ & 7.977 & $0.000^{*}$ \\
\hline $\begin{array}{l}\text { Average score for usual } \\
\text { activities. }\end{array}$ & $3.24 \pm 1.038$ & $3.61 \pm 0.0 .682$ & $3.17 \pm 0.953$ & $3.69 \pm 1.123$ & $4.33 \pm 0.577$ & $3.42 \pm 0.955$ & 8.532 & $0.000^{*}$ \\
\hline $\begin{array}{l}\text { Average score } \\
\text { pain/discomfort. }\end{array}$ & $3.89 \pm 0.614$ & $4.02 \pm 0.614$ & $3.71 \pm 0.743$ & $3.85 \pm 0.543$ & $4.33 \pm 0.577$ & $0.268 \pm 0.710$ & 2.986 & $0.033^{*}$ \\
\hline $\begin{array}{l}\text { Average score for } \\
\text { anxiety /depression. }\end{array}$ & $4.41 \pm 0.762$ & $4.39 \pm 1.000$ & $3.85 \pm 0.945$ & $4.73 \pm 0.452$ & $5.00 \pm 0.00$ & $4.30 \pm 0.903$ & 3.196 & $0.025^{*}$ \\
\hline $\begin{array}{l}\text { Overall average scores } \\
\text { for (EQ-5D). }\end{array}$ & $4.0865 \pm 0.54679$ & $4.2435 \pm 0.51106$ & $3.8625 \pm 0.71597$ & $4.2615 \pm 0.49886$ & $4.7333 \pm 0.11547$ & $4.1050 \pm 0.60603$ & 5.891 & $0.001 *$ \\
\hline
\end{tabular}

F: ANOVA test

(*) statistically significant $(\mathrm{P}<0.05)$

SD: standard deviation

$\mathrm{N}$ : number 
Table (8): Relation between Euro Quality of Life-5 Dimensions (EQ-5D) and sociodemographic data of study patients related to monthly income

\begin{tabular}{|c|c|c|c|c|c|c|}
\hline \multirow{3}{*}{$\begin{array}{l}\text { Euro QOL } \\
\text { dimensions }\end{array}$} & \multicolumn{4}{|c|}{ Monthly income } & \multirow{3}{*}{$\mathbf{t}$} & \multirow{3}{*}{$\begin{array}{c}\text { Test of } \\
\text { significance }\end{array}$} \\
\hline & \multicolumn{2}{|c|}{ Sufficient $(\mathrm{N}=100)$} & \multicolumn{2}{|c|}{ Insufficient $(\mathrm{N}=60)$} & & \\
\hline & Mean & SD & Mean & SD & & \\
\hline $\begin{array}{l}\text { Average score for } \\
\text { mobility. }\end{array}$ & 4.57 & 0.498 & 4.55 & 0.675 & 7.834 & $0.006^{*}$ \\
\hline $\begin{array}{l}\text { Average score for } \\
\text { self-care. }\end{array}$ & 4.44 & 0.701 & 4.25 & 0.968 & 9.775 & $0.002 *$ \\
\hline $\begin{array}{l}\text { Average score for } \\
\text { usual activities. }\end{array}$ & 3.49 & 1.040 & 3.30 & 0.788 & 10.803 & $0.001 *$ \\
\hline $\begin{array}{l}\text { Average score } \\
\text { pain/discomfort. }\end{array}$ & 3.84 & 0.707 & 3.93 & 0.548 & 6.554 & $0.011 *$ \\
\hline $\begin{array}{l}\text { Average score for } \\
\text { anxiety /depression. }\end{array}$ & 4.42 & 0.855 & 4.10 & 0.951 & 1.024 & 0.313 \\
\hline $\begin{array}{l}\text { Overall average } \\
\text { scores for (EQ-5D). }\end{array}$ & 4.1520 & 0.58335 & 4.0267 & 0.63935 & 0.142 & 0.706 \\
\hline
\end{tabular}

t: t- test

SD: standard deviation

$(*)$ : statistically significant $(\mathrm{P}<0.05)$

$\mathrm{N}$ : number

Table (9): Relation between Euro Quality of Life-5 Dimensions (EQ-5D) and sociodemographic data of study patients related to determinant length period postoperatively

\begin{tabular}{|c|c|c|c|c|c|c|}
\hline \multirow{3}{*}{$\begin{array}{l}\text { Euro QOL } \\
\text { dimensions }\end{array}$} & \multicolumn{4}{|c|}{$\begin{array}{c}\text { Determinant length period } \\
\text { postoperatively } \\
\end{array}$} & \multirow{3}{*}{$\mathbf{t}$} & \multirow{3}{*}{$\begin{array}{c}\text { Test of } \\
\text { significance }\end{array}$} \\
\hline & \multicolumn{2}{|c|}{$\begin{array}{c}\text { G1 } \\
\text { (One month and } \\
\text { half })(\mathrm{N}=80)\end{array}$} & \multicolumn{2}{|c|}{$\begin{array}{c}\text { G2 } \\
\text { (Three months) } \\
(\mathrm{N}=\mathbf{8 0})\end{array}$} & & \\
\hline & Mean & SD & Mean & SD & & \\
\hline $\begin{array}{l}\text { Average score for } \\
\text { mobility. }\end{array}$ & 4.16 & 0.538 & 4.96 & 0.191 & 12.527 & $0.000 *$ \\
\hline $\begin{array}{l}\text { Average score for } \\
\text { self-care. }\end{array}$ & 3.81 & 0.797 & 4.25 & 0.265 & 11.846 & $0.000 *$ \\
\hline $\begin{array}{l}\text { Average score for } \\
\text { usual activities. }\end{array}$ & 2.65 & 0.576 & 4.19 & 0.553 & 17.219 & $0.050 *$ \\
\hline $\begin{array}{l}\text { Average score } \\
\text { pain/discomfort. }\end{array}$ & 3.51 & 0.574 & 4.24 & 0.509 & 8.454 & $0.003^{*}$ \\
\hline $\begin{array}{l}\text { Average score for } \\
\text { anxiety /depression. }\end{array}$ & 3.94 & 1.035 & 4.66 & 0.550 & 5.531 & $0.000 *$ \\
\hline $\begin{array}{l}\text { Overall average } \\
\text { scores for(EQ VAS) }\end{array}$ & 3.3156 & 0.43709 & 4.3663 & 0.32343 & 17.282 & $0.000 *$ \\
\hline $\begin{array}{l}\text { Overall average } \\
\text { scores for (EQ-5D). }\end{array}$ & 3.6150 & 0.43838 & 4.5950 & 0.24644 & 17.430 & $0.000 *$ \\
\hline
\end{tabular}

SD: standard deviation

$\mathrm{N}$ : number 


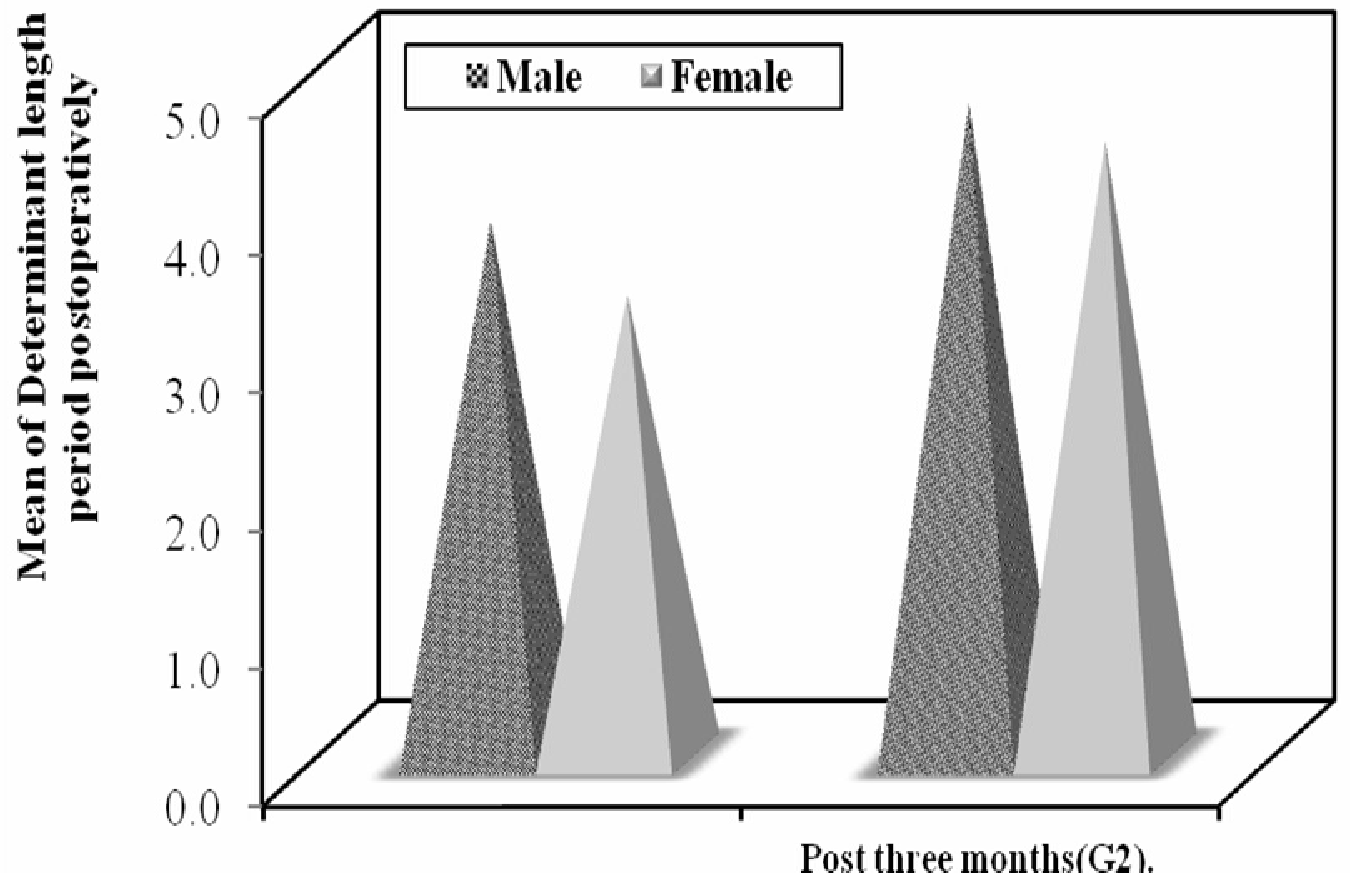

Figure (1): Presents comparison between overall average mean of Euro Quality of Life-5 Dimensions (EQ-5D) for patients sex and determinant length of period post CABG 


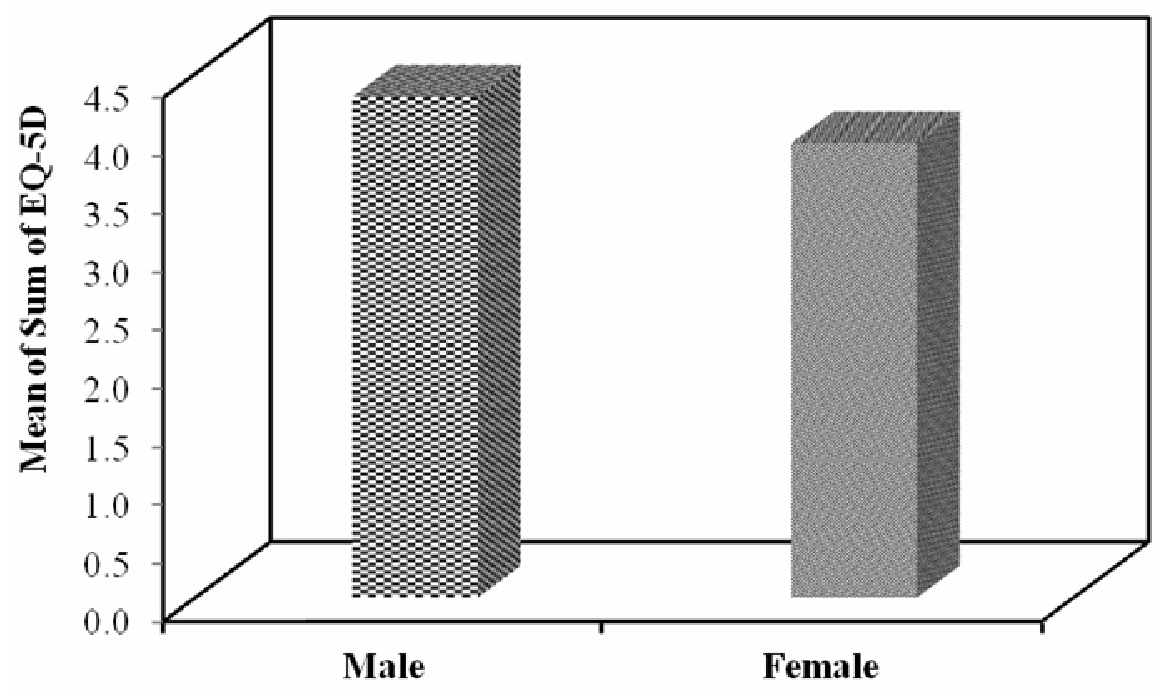

Figure (2): Presents comparison between overall average mean of Euro Quality of Life-5 Dimensions (EQ-5D) and sex post CABG

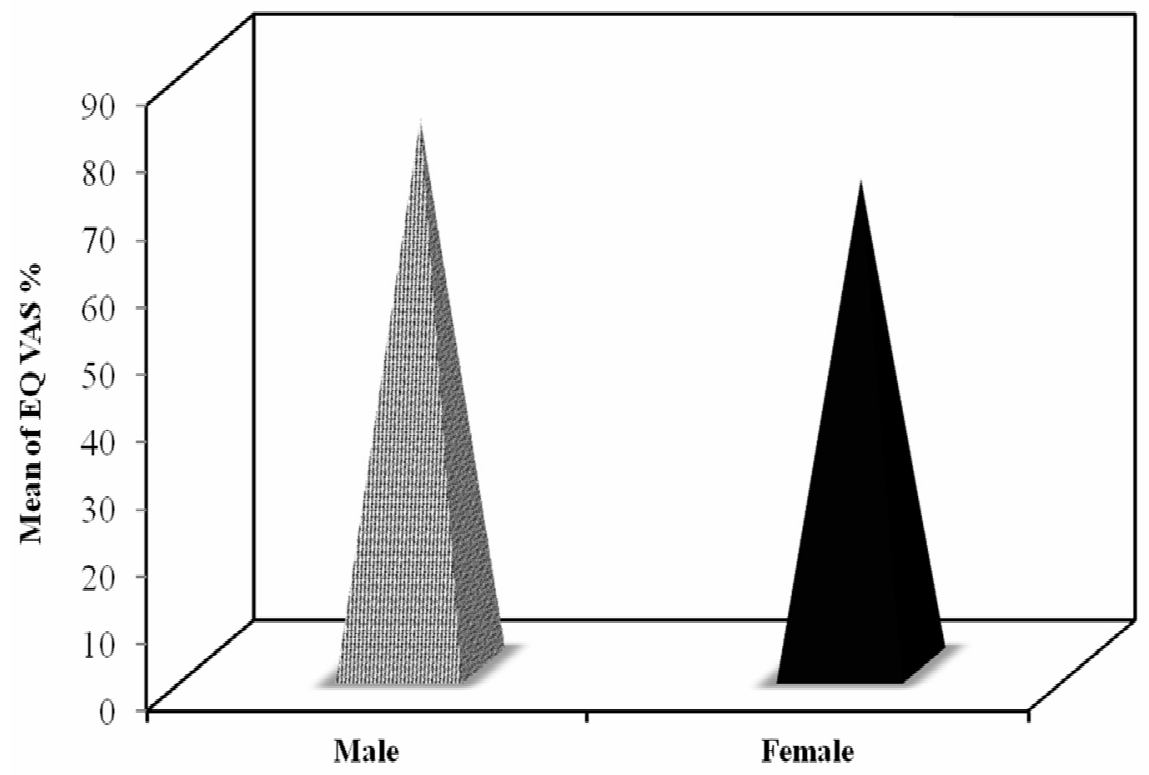

Figure (3): Presents comparison between Euro Quality of Life Visual Analogue Scale (EQ VAS) mean and sex post CABG 
Table (10): Multivariate analysis stepwise regression for 5 Dimensions

\begin{tabular}{|c|c|c|c|}
\hline Dimension & \multicolumn{3}{|c|}{ Mobility } \\
\hline Factors & B & $\mathbf{F}$ & Test of significance \\
\hline Postoperative period & 0.828 & $13.529^{*}$ & $0.001^{*}$ \\
\hline Occupation (house wife) & -0.277 & $4.151^{*}$ & $0.001^{*}$ \\
\hline Dimension & \multicolumn{3}{|c|}{ Self-Care } \\
\hline Factors & B & $\mathbf{F}$ & Test of significance \\
\hline Postoperative period & 1.118 & 12.926 & $0.001^{*}$ \\
\hline Sex & -0.467 & 5.401 & $0.001^{*}$ \\
\hline Dimension & \multicolumn{3}{|c|}{ Usual activities } \\
\hline Factors & B & $\mathbf{F}$ & Test of significance \\
\hline Postoperative period & 1.579 & 21.106 & $0.001^{*}$ \\
\hline Sex & -0.587 & 7.217 & $0.001^{*}$ \\
\hline Occupation(not work) & 0.307 & 2.969 & $0.003^{*}$ \\
\hline Age & -0.099 & 2.124 & $0.035^{*}$ \\
\hline Dimension & \multicolumn{3}{|c|}{ Pain/discomfort } \\
\hline Factors & $\mathbf{B}$ & $\mathbf{F}$ & Test of significance \\
\hline Postoperative period & 0.729 & 8.924 & $0.001^{*}$ \\
\hline Sex & -0.337 & 4.127 & $0.001^{*}$ \\
\hline Dimension & \multicolumn{3}{|c|}{ Anxiety/depression } \\
\hline Factors & $\mathbf{B}$ & $\mathbf{F}$ & Test of significance \\
\hline Postoperative period & 0.808 & 6.747 & $0.001^{*}$ \\
\hline Occupation(house wife) & -0.651 & 4.779 & $0.001^{*}$ \\
\hline Occupation(not work) & 0.356 & 2.110 & $0.036^{*}$ \\
\hline
\end{tabular}

F: ANOVA test.

B:Beta value.

* Significant at $\mathrm{P} \leq 0.05$ 


\section{References}

1. Taghadosi M, Aliakbarzade Z, Reza H. Quality of life in patients with ischemic heart disease. Nursing and Midwifery Sciences Journal 2014; 1(1): 19-26.

2. Mandal S, Saha J, Mandal S, Bhattacharya R, Chakraborty M, Pratim P. Prevalence of Ischemic Heart Disease among Urban Population of Siliguri, west Bengal. Indian J Community Med 2009; 34(1): 19-23.

3. Suliman A. The State of Heart disease in Sudan. Cardiovasc J Afr 2011;22(4):191-6.

4. Yousefi P, Sabzevari S, Mohammad S, Haghdoost A. Studying life quality in Heart Failure Hospitalized Patients Nursing Research Journal 2011; 6(21): 59-67.

5. Phipps W, Marek J, Manahan F, Neighbor S. Sands J, Green O. MedicalSurgical Nursing. Health and Illness Perspectives 7th ed. Missouri: Mosby, 2003.

6. Roohafza H, Sadeghi M, Boshtam M, Rabiei K, Khosravi E. Effects of a cardiac rehabilitation course on psychological stresses in an Iranian population. ARYA Atherosclerosis J 2012: 7: 74-7.

7. Abd Elfattah E. Life Style Modification to Reduce Occurrence of Coronary Artery Disease among Adult Women. Master thesis. Faculty of Nursing: Menoufia University, 2012.

8. Tillmanns H, Erdogan A, Sedding D. Treatment of chronic CAD--do the guidelines (ESC, AHA) reflect daily practice? Herz 2009; 34(1):39-54.

9. Yuk P. The Patients' Lived Experiences After Coronary Artery Bypass Graft Surgery. Master thesis. Faculty of Nursing: Hong Kong University; 2005.

10. Delmo W, Hetzer R. Surgical treatment concepts for heart failure. HSR Proc
Intensive Care Cardiovasc Anesth 2013; 5(2): 69-75.

11. ACC/AHA Pocket Guideline, Based on the ACC/AHA 2007Guideline Revision. Management of Patients with Unstable Angina/Non-ST Elevation Myocardial Infarction 2007. Available at: http://my.clevelandclinic.org/.../treatmen t medica 1 .

12. Montalescot G, Sechtem U, Achenbach S, Andreotti F, Arden C, Budaj A, et al. 2013 ESC guidelines on the management of stable coronary artery disease: the Task Force on the management of stable coronary artery disease of the European Society of Cardiology. Eur Heart J 2013; 34(38): 2949-3003.

13. Boden W. Surgery, angioplasty, orsymptomatic multivessel coronary artery disease. Am Coll Cardiol J 2004; 43(10): 1752-4.

14. Diodato M, Chedrawy E. Coronary Artery Bypass Surgery: The past, present, and future of Myocardial Revascularization. Surg Res Pract 2014; 2014: 726158 .

15. Griva K, Theofilou P. The Study of Quality of Life. EurPsychol J 2009; 41(9): 3693-6.

16. World Health Organization. Measuring Quality of Life.2007.

17. Berend N. Measuring the Impact of Asthma on Quality of Life in the Australian Population (C) Australian Institute of Health and Welfare 2004.

18. Guru V, Frames S, Austin P. Gender Differences in Outcomes After Hospital Discharge From Coronary Artery Bypass Grafting. Circulation 2006; 113 (4): 507-16.

19. Lindquist $\mathrm{R}$,Dupuis G, Terrin M, Hoogwerf B. Comparison of Health Related Quality of Life Outcomes of Men and Women After Coronary Artery 
Bypass Surgery Through 1 Year. Am Heart J 2003; 146(6):1038-44.

20. Patel K, Mark A. Do women fare worse than men following cardiac surgery? Society of Cardiovascular Anesthesiologists Organization 2005.

21. Brown I, Brown R. Quality of Life and Disability: An Approach for Community Practitioners. $2^{\text {nd }}$ ed. London: Jessica Kingsley; 2004; 17-27.

22. Kadda O, Marvaki C, Panagiotakos D. The Role of Nursing Education after A cardiac Event. Health Science Journal 2012; 6(4): 634-40.

23. Jalilian M, Mostafavi F, Sharifirad Gh. Association between Self-Efficacy, Perceived Social Support and Quality of Life in Patients with Cardiovascular Diseases: A Cross-Sectional Study. Health Syst Res J 2013; 9(5): 531-9.

24. Bajenaru O, Antochi F, Tiu C. Particular aspects in patients with coronary heart disease and vascular cognitive impairment. Neurol Sci J 2010; 299 (1):49-50.

25. Kerestes P, Merritt S, Holm K, Penckofer S, Patel M: The coronary artery bypass experience: gender differences. Heart Lung. 2003, 32: 308319.

26. Bahramnejad F, Asadi Noughabi A, Sief $\mathrm{H}$, mohammadi Y. Quality of life in the patients with coronary bypass graft. INR J 2012; 7 (26): 34-41.

27. Kołtowski Ł, Drohomirecka A, Palczewski M, Cichoń R. Short-Term Improvement of Patients' Quality of Life After Coronary Artery Bypass Graftinga Prospective Single-Center Study Based on the EQ-5D Assessment Tool. Advanc Clin Exp Med J 2011; 20(4): 447-53.

28. Rahimi A, Taghipoor H, Pourebrahimi M. Comparing patients' quality of life before and after Coronary Artery Bypass Graft surgery (CABG). Iran Cri Care Nurs J 2014; 7(3): 194-9.
29. Mullany C. Coronary Artery Bypass Surgery. Circulation J 2003; 107:21.

30. Chan D, Chau J, Chang A. Acute coronary syndromes: cardiac rehabilitation programs and quality of life. Adv Nurs J 2005; 49 (9): 591-9.

31. American Heart Association. Management of Patients with Unstable Angina/Non-ST Elevation Myocardial Infarction 2007.

32. Tranmer J, Parry M. Enhancing postoperative recovery of cardiac surgery patients. West Nurs Res J 2004; 26(5): 512-32.

33. Parry M, Watson J, Hodnett E. Pain experiences of Men and Women after Coronary Artery Bypass Graft Surgery. Cardiovasc Nurs J 2012; 25(3): 9-15.

34. McKhann G, Borowicz L, Goldsborough M, Enger C, Selnes O. Depression and cognitive decline after coronary artery bypass grafting. Lancet 1997; 349: $1282-84$.

35. Tully P, Baker R. Depression, anxiety, and cardiac morbidity outcomes after coronary artery bypass surgery: A contemporary and practical review. J Geriatr Cardiol 2012; 9: 197-208.

36. McCrone S, Lenz E, Tarzian A, Perkins S. Anxiety and depression: incidence and patterns in patients after coronary artery bypass graft surgery. Nurs Res 2001:14: 155- 64 .

37. Studzińska K, Nowobilski R, Furgał M, Czyż P. Fielek D,Kolczynski G. et al.the drug analysis and depression in patients after CABG. Ann Acad Med Gedan 2006; 36: 183-9.

38. Nieradko B, Stepnowska M. Depression in patients after coronary artery bypass grafting. Psychiatric Polska Journal; 2011; 69(2): 202- 5 .

39. Markou A, Windt A, Henri A. Changes in quality of life, physical activity, and symptomatic statusone year 
after myocardial revascularization for stable angina. Eur Cardiothorac Surg J 2008; 34:1009-15.

40. Baig K, Harling L, Papanikitas J, Attaran S, Ashrafian H, Casula R, Athanasiou T. Does coronary artery bypass grafting improve quality of life in elderly patients?. Interact Cardiovasc Thorac Surg 2013; 17:542-53.

41. Irfan S, Rahaman M, Noman A, Mithun S. Health Related Quality of Life Among Coronary Artery Bypass Graft Patient Attended at Combined Military Hospital, Dhaka. AKMMC J 2013; 4(2): 10- 7 .

42. Maggioni A, Dahlstrom U, Filippatos G, Chioncel O, Leiro M, Eur observational research programme: The heart failure pilot survey (ESC-HF Pilot). Eur J 2010; 12(10): 1076-84.

43. Norris C, John A, Kathleen M, William A. Sex and Gender Discrepancies in Health-Related Quality of Life Outcomes among Patients with Established Coronary Artery Disease. Circulation Cardiovascular Qual Outcomes journals 2008; 1: 123-30.

44. Nogueira C, Hueb W, Takiuti M, Girardi P, Nakano T, Fernandes F, et al. Quality of Life after On-Pump and Off-Pump Coronary Artery Bypass Grafting Surgery. Arq Bras Cardiol 2008; 91(4): 217-22, 238-44.

45. Hunt J, Hendrata M, Myles P. Quality of life 12 months after coronary artery bypass graft surgery. Heart \& Lung 2000; 29: 401-11.

46. Kaur M, Kumar A, Kumari S. Quality Of Life And Lifestyle Of Patients Before And After Coronary Artery Bypass Grafting (CABG). Nursing and Health Science journals 2013; 2(3):10-5.

47. Douki Z, Vaezzadeh N, Shahmohammadi S, Shahhosseini Z, et al. Anxiety Before and after Coronary Artery Bypass Grafting Surgery: Relationship to QOL. Middle-East Scientific Research Journal 2011; 7(1): 103- 8.

48. Hos E, Siah N, Zaidah Z, Teoh K, et al. Quality Of Life amongst Post Coronary Artery Bypass Patients at the National Heart Institute, Malaysia. Med \& Health journal 2010; 5(2): 77-85.

49. Sabzmakan L, Hazavehei S, Morowatisharifabad M, Hasanzadeh A, Rabiee K, Sadeqi M. The effects of a PRECEDE-based educational program on depression, general health, and quality of life of coronary artery bypass grafting patients. Asian Psychiatry Journal 2010; 3:79-83.

50. Mark A, Lam L, Lee K, Channing N, et al. Job strain and the prevalence and outcome of coronary artery disease. Circulation Journal 1995; 92:327- 33.

51. Yousefi P, Sabzevari S, Mohammad S, Haghdoost A. Studying life quality in Heart Failure Hospitalized Patients in Kerman Medical University Hospital in 2008. Nursing Research Journal 2011; 6(21): 59-67.

52. Dueoas M, Salazar A, Ojeda B, Failde I. Health Related Quality of Life in Coronary Patients, Recent Advances in Cardiovascular Risk Factors. $1^{\text {st }}$ ed. Rijeka: Croatia, 2012; 522.

53. Okkonen E, Vanhanen H. Family support, living alone and subjective health of patients in connection with a coronary artery bypass surgery. Heart Lung Journal 2006; 35:234-44.

54. Kaur M, Kumar A, Kumari S. Quality Of Life And Lifestyle Of Patients Before And After Coronary Artery Bypass Grafting (CABG). Nursing and Health Science journals 2013; 2(3)10-5. 